\title{
Demographic Factors Associated with Retirement Planning: A Study of Employees in Malaysian Health Sectors
}

\author{
Mohd Fitri Mansor ${ }^{1}$, Chor Choon Hong ${ }^{1}$, Noor Hidayah $\mathrm{Abu}^{2} \&$ Mohd Shahidan Shaari ${ }^{1}$ \\ ${ }^{1}$ School of Business Innovation \& Technopreneurship, Universiti Malaysia Perlis, Kangar Perlis, Malaysia \\ ${ }^{2}$ School of Technology Management and Logistic, College of Business, Universiti Utara Malaysia, Sintok Kedah, \\ Malaysia \\ Correspondence: Mohd Fitri Mansor, School of Business Innovation \& Technopreneurship, Universiti Malaysia \\ Perlis, Kangar Perlis, Malaysia. E-mail: fitrimansor@unimap.edu.my; jorchor@gmail.com; dayah@uum.edu.my \\ shahidanshaari@unimap.edu.my
}

Received: November 24, 2014 Accepted: March 3, 2015 Online Published: May 16, 2015

doi:10.5539/ass.v11n13p108 URL: http://dx.doi.org/10.5539/ass.v11n13p108

\begin{abstract}
Retirement is a stage of life where involvement in certain social activities and desirable conducts become less or narrow. Retirement life without planning requires continuous employment or working and the life style remain same with young age although the individual reaches retirement age. Lack of proper retirement planning preparation will generally bring some disappointment during retirement. Thus, having a proper retirement planning is extremely important. The main aim of the study is to investigate the significant of demographic factors in determining of retirement planning among health sectors based employees. While, the objectives of the current study are to determine the relationship between demographic factors consists of age, education level, gender and household income towards retirement planning. There are 110 set of questionnaires distributed to respondents worked in health sectors. The results of the study revealed that age; education level and household income were supported however intriguing findings for gender was not supported. The findings and the framework of the study will be useful to the Malaysians in preparing a proper retirement planning in their life. The study also serves a guideline to the government and policy maker as well as banking and financial institutions in satisfying the needs and wants from the market.
\end{abstract}

Keywords: retirement planning, demographic factor, age, education, income and gender

\section{Introduction}

The growing of life expectancy among Malaysians in past few decades has shown that Malaysians will experience longer retirement life (Yip, 2009; Hunt, 2009). Today, many problems arise in preparing the retirement plan due to natural biological aging process, workers types, retirement age policy, family cultural changes, unpredictable macroeconomic events, medical cost increases and so on. Pointing to existing poor retirement planning practices among Malaysian which relying much on savings, Employee Provident Fund (EPF) and children, proper actions must be done (Hunt, 2009; HSBC, 2010). These facts highlight the raising concern and awareness of retirement planning among Malaysians is much needed. Furthermore, the retirement age in Malaysia had increased from 56 to 60 years old signaled the proper retirement planning is become more pertinent. In view of that, poor and lack of retirement planning behavior and challenges ahead that will contribute the life of retirees. Therefore, this study is important in creating new knowledge of better understanding of the underlying demographic factors faced in implementing the retirement planning. Specifically, the objectives of the current study are to examine the relationship between demographic factors consists of age, education level, gender and household income towards retirement planning among Health sectors employees.

Over the past few decades, life expectancy has risen drastically of about 2 to 3 years for each decade and this number is expected to further increase in the future (Selene, 2005). As for the rising figures, financial planning for retirement becomes more important. Retirement planning varies from one another but can be observed by integrating individual's intention and behavior that are partially different or unknown to one another (Hanisch, 1995). Retirement is defined as a stage of life where involvement in certain social activities and desirable conducts become less or narrow less. It is represents a stage of life where involvement in certain social activities and desirable conducts become less; become narrow or few roles when the person reached the old ages (Parsons, 
1942). Retirement life without planning requires continuous employment or working and lifestyle which remain same with young age although that individual reaches retirement age (Lee \& Law, 2004). Lack of retirement planning preparation will generally bring some disappointment during retirement and yet preparation for retirement planning is not an easy task (Lee \& Law, 2004). Thus, having a retirement planning is extremely important.

Previous literatures on retirement planning focused on studies to identify the relationship of socio-demographic factors to be related to the retirement planning (Joo \& Garman, 1998; Lee \& Law, 2004; DeVaney, 1995; Yakoboshi \& Dickemper, 1997). They emphasized on income, age, gender, education level and material status are all important factors for one's behavior towards retirement planning. DeVaney (1995) identified that income and age are important to guild pre-retirees in groundwork process of planning. In addition, gender differences also influence the early preparation for retirement planning (Yakoboshi \& Dickemper, 1997). Retirement education and certain related programs also affect the retirement planning behaviors (Joo \& Grable, 2001).

Xiao (1995) found that having sufficient income is a main to minimize some problems during retirement. Income level is an important factor determinant for retirement wealth growth. Different types of planning will lead to different ways of wealth accumulations and lifestyle during retirement (Lusardi \& Mitchell, 2007). At the same time as retirement planning involves awareness and understanding of the problem underlines in life, individual's perception is strictly important to achieve the highest retirement satisfaction (Xiao, 1995). Besides, Taylor-Carter, Cook and Weinberg (1997) identified that proper planning will improve one's confidence and self-efficacy towards uncertainty typically in short or long time frame in retirement age. Based on previous studied in developed countries on retirement planning issues such as in United States (Joo \& Grable, 2001; Taylor-Carter et al., 1997; Duflo \& Saez, 2002), Hong Kong (Lee \& Law, 2004), and Singapore (Lim, 2003). These studies involved the Baby Boomer generation (DeVaney, 1995; Glass \& Kilpatrick, 1998; Ekerdt \& DeViney, 2001; Lusardi \& Mitchell, 2008). In addition, the study also involved wide issues related to woman in retirement planning such as the longevity life of women rather than men, women economic and psychological issues, factors affecting retirement planning and women financial literate. The result shows the majority of women do not plan for retirement (Glass \& Kilpatrick, 1998; Lusardi \& Mitchell, 2008) and less financial literature as well as economically and psychologically weak in retirement planning (Glass \& Kilpatrick, 1998; Lusardi \& Mitchell, 2008).

Increasing life expectancy of Malaysian has raised the concern on retirement issues. Latest statistical findings from United Nation Statistical Division (2010) provide that life expectancy at birth of Malaysians for women and men in 2005 to 2010 has increased from 72 to 76.7 years. In addition, the United Nation data also reviews that Malaysia is expected to have a total number of 3.2 million individuals who aged 60s and above by 2020 (Yip, 2010). These figures tell us that more Malaysians will reach retirement age and with the longer life expectancy among Malaysian. It means that without extending the retirement age, a typical Malaysian will have longer time to spend in their retirement life. Consequently, it is important to create awareness towards the importance of retirement planning.

In addition, current retirement planning practices among Malaysians are basically relying much on savings, Employee Provident Fund (EPF) and their children. Majority of them are not actively involved in retirement planning (Hongkong and Shanghai Banking Corporation [HSBC], 2010). Although, about $72 \%$ of Malaysian having high propensity to save in retirement, $41 \%$ do not have solid plan on how to build their retirement fund (Hunt, 2009). Many of them rely more on fixed deposit and savings accounts that lead low interest yield. They have failed to segregate part of their saving for retirement needs. The money in savings is in essence for all purposes without specific purposes for retirement (Hunt, 2009). The alarming here is that majority of Malaysian might not insufficient source of income and there might be some risk involve if retirement planning is not done correctly during their retirement life (HSBC, 2010).

Based on an evidence from the previous research in retirement planning, there is still lack of retirement planning can be observed in Malaysia (Hunt, 2009). The relativity low per capital income among the Malaysians might limit the applicability of the studies conducted in more developed countries to Malaysia context (Muzaffar, 2010). Therefore, this study is important to explore and to gain the understanding and knowledge on how Malaysians plan of their retirement mainly on demographic.

In order to address the research gap, this study will focuses to the extent on understanding level among Malaysians towards retirement, to examine the Malaysians' awareness, to investigate how Malaysian prepare their retirement life as well as to identify the factors might affect toward their retirement planning. Although there are many researches interest on retirement planning, focuses will be given on demographic factors consist 
of age, education level, gender and income. The reviews those variables studied will be discussed in the following paragraphs.

\section{Demographic Factors}

Among the factors related to retirement planning plans, age, education level, gender, and household income are characterized as important demographic factors toward individual retirement preparation. The following parts will further discuss the demographic variables from the review of literature in details.

\subsection{Age}

Several studies examine the effect of age on retirement shown that age to be related to retirement plan and decisions. Age has emerged as an important and consistent factor in human behavior towards retirement planning (Richardson \& Kilty, 1989; Joo \& Pauwals, 2002; Devaney, 1995). Age can help to guide pre-retirees and individuals in ground work process of planning (DeVaney, 1995), lead to attitude and perception changes on retirement and also help to raise retirees and individuals retirement confidence (Joo \& Pauwels, 2002). Besides, Lee and Law (2004) concluded that individuals are more motivated to take action for retirement as their age and income increases. This statement is supported by Montalto, Yuh and Hanna (2000) where as they found that planned retirement age are guided by reinforcement given from constant visit or review on the information needed for planning.

Again, income and age are found to be correlated in influencing one's behavior towards retirement planning (Lee \& Law, 2004). DeVaney (1995) concluded that age and other demographic variables such as educational level, household incomes and size are inter-related to guide pre-retirees in groundwork process of planning but this study is contradict with other DeVaney, Gorham, Bechman and Haldeman (1995) finding where age is found to have negative relationships to saving decisions suggesting that regular saving is the common practices for younger respondents. Age has also shown to be important in the area of future educational program (Joo \& Garman, 1998). On the other hand, Xiao (1995) uncover more compelling evidence on the factors affecting perceived adequacy of retirement income for pre-retired household, the finding suggest that different respondents' age is likely to give different perception on income adequacy. The average individual tend to retire 3 years before the expected age (Zappala \& Depolo, 2008) and the different between expected and preferred retirement age are: chronological age, work condition variables, perceive of income adequacy as well as attitude towards retirement. Hence, the age can be hypothesized as below:

\section{Hypothesis 1: Age has a significant impact towards retirement planning}

\subsection{Education Level}

In general, there are also extensive studies on retirement covering education level. The findings suggest that education level is one of important factors affecting retirement planning preparation (Hogarth, 1985; Joo \& Pauwels, 2002). According to Joo \& Pauwels (2002), sources of information will influence individual's attitude, decisions and intention towards retirement planning and the information of education can also help individuals to explore more regarding their retirement planning. In addition, Devaney (1995) mentioned that the effect of education level can be serving as a motivator or guidance for individuals to start the retirement planning preparation. Individual tend to be more motivated to concern on retirement planning preparation as well as take action for their retirement when increase in the age and the education level.

Furthermore, Joo and Pauwels (2002) addressed that individuals may experience and achieve better confidence level in their retirement planning life when they have higher education level. Men who had received higher education level tended to be more confident and do better in their retirement planning compared to people who had received lower levels of education level. Hence, the level of education and confidence found to be positively related. On the other hand, in general, because of limited education which had been given to them in the past, older women are found less likely to have higher education (Lusardi, 2004). The effect of education on women's retirement makes women to be having less knowledge and less financial literature on retirement and also retirement planning (Lusardi, 2004; Lusardi \& Mitchell, 2008). Joo and Pauwels (2002) also suggested that women participation in retirement planning preparation increases as they receive higher education.

In addition, Joo and Garman (1998) provide a good overview that education levels are significant to focus topic for future financial education programs. People who highly educated generally tend to possess and receive more investing knowledge on retirement planning compared to those who are less educated. According to Bernheim (1994), education makes the possible of enhancing and exploring more knowledge and information on retirement for individuals and workers. Therefore, hypothesis of education as below:

Hypothesis 2: Education level has a significant impact towards retirement planning 


\subsection{Gender}

Instead of age and education level will affecting on retirement planning. Gender difference is also a significant predictor in retirement planning studies. According to Yakoboshi and Dickemper (1997), gender difference can be considered as the major influential factor for early preparation in retirement planning due to men and women are generally will think and act differently in term their views and expectations. Men are found to be better prepared and ready for their retirement planning compared to women (Lusardi \& Mitchell, 2008). In addition, Glass and Kilpatrick (1998) mentioned that women tend to be less prepared of their retirement planning due to lack of adequate financial resources than men. They generally found to be more economically and psychologically weak in retirement planning and are influenced by several factors such as limited economic accessibility, pension scheme, low wage, gender prejudice as well as selection of career option in their intention towards effective planning (Glass \& Kilpatrick, 1998).

Several previous findings revealed that individuals regardless of men or women who are more financially literate, richer tend to be more tolerance to risk as well as attitude towards retirement are among important factors in affecting an individual decision in planning for retirement and seek professional assistance in retirement planning (Duflo \& Saez, 2002; Lusardi, 2007). Gender difference do not bring any effect to the decision making on retirement as Joo and Grable (2001) highlight that the likelihood of both genders' behavior on professional retirement help-seeking are the same, however, women involvement rate in seeking help from professional are slightly higher compare to men if they are given a chance. They more likely to seek financial advice from experts and professional and those women who have better financial knowledge and literature tend to do better and more successful in their retirement planning (Lusardi, 2004; Lusardi \& Mitchell 2008).

Lusardi and Mitchell (2008) also pointed out that majority of women do not have any idea and plan to do their retirement planning and most of them only depend on the support from their friends and family during retirement age due women are less equipped with financial knowledge and financially literature compared with men. On the other hand, Sunden and Surette (1998) also addressed that, gender difference and marital status have significant relationships when come to investment decision on retirement planning. These factors will generate different level of assets distribution among women and men in retirement planning (Sunden \& Surette, 1998). Recent finding by Grace, Weaven and Ross (2010) indicates that men and women do not think, perceive, and act for retirement planning in the same way.

There are 21 exploratory semi-structured interviews has been conducted to explore and identifying regarding this differences, the result shows that men are likely to go for their own individual choice perspective while women tends to adopt life course perspective when it comes to retirement planning. Besides, men think and perceive retirement as another stage of life in the future while women make less prediction on future life stages. Therefore, the gender can be hypothesized as below:

\section{Hypothesis 3: Gender has a significant impact towards retirement planning}

\subsection{Income}

Next, demographic variable studied in relation to retirement planning is income. Income level is perhaps another important variable. Income is important in the sense that one's must have enough money or wealth resources in order to make retirement preparation work (Richardson \& Kilty, 1989). According to Ruhm (1989), individual's preparation on retirement income varies from one another. Identifying adequacy of income during retirement age is not an easy task. In addition, Joo and Grable (2001) identified that among other socioeconomic aspects, most of the time the attitude towards help-seeking from professional towards retirement planning is partially influence and control by income factor. The statistical analysis shows that people who have higher income are more motivated to seek professionals help regarding investment-related decision, but the people who come from lower income group which had less income are less likely to look for professional help on retirement investment decisions. For this reason, income can be considered very much associated to the retirement income source (Richardson \& Kilty, 1989).

Based on Kim, Kwon and Anderson (2005) addressed that attitude and behavior towards retirement are influence by income in general. Income is a critical and essential measurement in some matter relating to retirement especially when in retirement education program (Joo \& Garman, 1998) and professional financial help-seeking (Joo \& Grable, 2001). According to Joo and Garman (1998), income will definitely impact on the financial education programs topic which workers are looking for. This study identified that worker tend to pursue differently in types financial education available based on monthly income. Workers who come from higher income group are more preferable on financial education on estate planning while workers with lower levels of income more preferable on financial education on debt clearance, mortgage purchasing and budgeting. Therefore, 
income can be hypothesized as below:

\section{Hypothesis 4: Income level has a significant impact towards retirement planning}

\section{Methodology}

Based on the previous reviews, the theoretical framework of the current study illustrated as below:

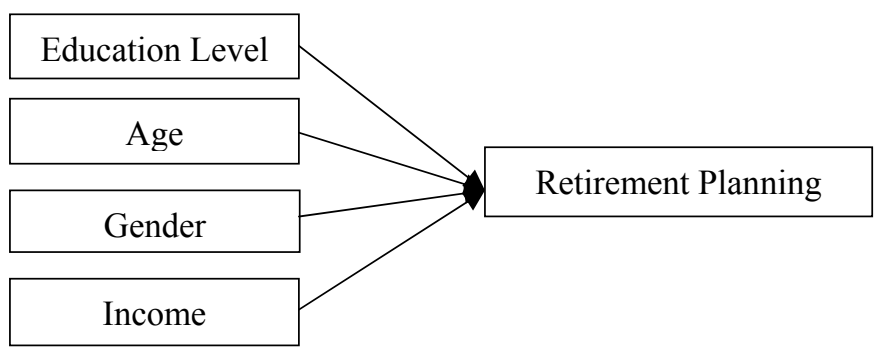

Figure 1. Theoretical framework

\subsection{Unit of Analysis}

The aim of current study is to investigate the relationship between demographic background such as age, education level, and gender and income level. Therefore, the study is correlation study. Since the aggregations of data in subsequent analyses on individual level, the unit of analysis in the present study is employee in Department of Food Safety \& Health (DOFSH) and Department of Health (DOH) consist of 110 employees as illustrate in Table 1 as below.

Table 1. Population

\begin{tabular}{ll}
\hline Sectors (Government Servant) & Number of employees \\
\hline Department of Food Safety \& Health (DOFSH) & 40 \\
Department of Health (DOH) & 70 \\
Total & 110 \\
\hline
\end{tabular}

\subsection{Sample Size and Sampling Technique}

The sample size of current study is based on table size by Sakeran (2000). According to him, 110 respondents in a population, it is about 80 respondents need to be selected as a sample size to represent overall population. To ensure the questionnaire returns are sufficiently, $100 \%$ set of questionnaires will be distributed to the respondents to cover incorrect data, data error, missing data and questionnaires distributed but no return. The sampling technique used in this research is simple random sampling where respondent is randomly chosen in both sectors.

\subsection{Data Analysis}

Data gathered from respondents were analysed by using SPSS 19.0. This statistical tool is used to analyse the relationship between the variables to meet the objectives of research. However, the independent variable which is demographic factor is unable to test by using reliability analysis, correlation analysis as well as linear regression evaluation. Therefore, to test between demographic factors and retirement planning is using cross tabulation analysis in SPSS.

\section{Findings}

Table 2. Sample profile

\begin{tabular}{ll}
\hline Items & Total Questionnaire \\
\hline Number of questionnaire distributed & 100 \\
Number of questionnaire collected back & 80 \\
Response rate & $80 \%$ \\
Number of questionnaire used for analysis & 80 \\
\hline
\end{tabular}


Table 2 below shows the sample profile of the questionnaire survey. A total of 100 sets of questionnaire were randomly distributed to the selected respondents in both sectors. However, only 80 sets of questionnaire were collected back which make up of $80 \%$ of total number of questionnaire that distributed.

\subsection{Descriptive of Demographic Profile}

Table 3 summarized demographic data of the respondents which including gender, race, age, educational level, income level, marital status in both sectors. There are 36 males and 44 females' respondents were answered the questionnaire throughout this study. One respondent is being removed from the table 3 because of no disclosure of demographic information. The respondents' age distribution is range from 21 to 60 years old and all of the respondents are from working group. In term of ethnicity, there are 71 Malays respondents, 3 Chinese, 3 Indian and 3 others ethnicity such as Siamese was answered the questionnaire.

The monthly income distribution is divided into 4 categories. Category " 1 " is for income less than RM1000 which consist of 2 respondents ; Category "2" is for income from RM1000 - RM3000 consist of 53 respondents; Category " 3 " is for income RM3000 - RM5000 consist of 20 respondents and there are only 5 respondents in Category "4" is for income RM5000 and above. Besides, education level is divided into 15 respondents from high school, 47 respondents from college, 10 respondents are undergraduate degree, 2 respondents are postgraduate degree and 2 professional respondents. There are 22 respondents are single and 58 respondents are married.

Table 3. Demographic profile

\begin{tabular}{llll}
\hline Variables & Categories & Frequency & Percentage (\%) \\
\hline \multirow{2}{*}{ Gender } & Male & 36 & 45 \\
& Female & 44 & 55 \\
Race & Malay & 71 & 88.8 \\
& Chinese & 3 & 3.8 \\
& Indian & 3 & 3.8 \\
& Others & 3 & 3.8 \\
Age & 21 -30 years old & 30 & 37.5 \\
& 31 - 40 years old & 26 & 32.5 \\
& 41 - 50 years old & 10 & 12.5 \\
Educational Level & 51 - 60 years old & 14 & 17.5 \\
& 60 Above & - & - \\
& High School & 15 & 18.8 \\
Diploma & 47 & 58.8 \\
Marital Status & Under degree & 10 & 12.5 \\
& Post degree & 6 & 7.5 \\
Income level & Professional & 2 & 2.5 \\
& Married & 58 & 72.5 \\
& Single & 22 & 27.5 \\
& Less than RM 1000 & 2 & 2.5 \\
& RM 1000 - RM 3000 & 53 & 66.3 \\
& RM 3000 - RM 5000 & 20 & 25.0 \\
& RM 5000 Above & 5 & 6.3 \\
\hline
\end{tabular}

\subsection{Cross Tabulation Analysis}

Since demographic background is in the form of nominal but not scale, the analysis cannot run as usual by using reliability analysis, correlation analysis and regression analysis. However, demographic background does not requires reliability analysis, hence; this section will only focus on correlation between independent variable which is demographic background and retirement planning by using cross tabulation analysis. There are 4 elements in demographic background that focused by the researcher which are age, education level, genders and income level as well. The results can be obtained from Chi-Square Tests. 
Table 4. Cross tabulation chi-square test result

\begin{tabular}{llll}
\hline Demographic variables & Chi-Square Value & df & $\begin{array}{l}\text { Asymp.Sig.(2-sided) } \\
\text { P-Value }\end{array}$ \\
\hline Age & 13.991 & 12 & 0.301 \\
Education Level & 26.379 & 16 & 0.049 \\
Genders & 2.197 & 4 & 0.700 \\
Income Level & 12.128 & 12 & 0.435 \\
\hline
\end{tabular}

Table 4 above provides the summary statistic information regarding age, education level, genders and income level. This study only wants the data on "Pearson Chi-Square" row. The Chi-Square value is under "value" and the p-value is under "Asymp. Sig." Based on the above table, the Chi-Square value for age is 13.991 and p-value is 0.301 , which associated $30.1 \%$ risk of being wrong in rejecting the null hypothesis. In other words, it means that $69.9 \%$ relationship between age and retirement planning. Hence, hypothesis 1 age has a significant impact towards retirement planning is accepted.

Next, is education level, the Chi-Square value is 26.379 and p-value is 0.049 , it is a very strong positive relationship between education level and retirement planning which 95.1\%. Besides, the Chi-Square value for genders is only 2.197 and p-value high as 0.700 , it means there is only $30 \%$ relationship between genders and retirement planning. Since the percentage below than $50 \%$, it is consider that there is no relationship between these 2 variables. The last elements in demographic background is income level, the Chi-Square value for income is 12.128 and p-value is 0.435 , this prove that $56.5 \%$ relationship between income level and retirement level, the relationship actually not so strong as others, but since the percentage more than $50 \%$, it is considers that there is a relationship between these 2 variables.

\section{Discussions}

The current study was conducted on the importance of retirement planning among health sectors based employees in the context of powerful of demographic influence. The variables involved in the study focused on demographic i.e. age, education level, gender and income level, attitudes as towards retirement planning. Specifically the objectives of the current study are to determine the relationship between demographic towards retirement planning among health sectors based employees. The study was made arising from the life expectancy in Malaysia is predicted to increase in coming years, Malaysians are therefore would have a longer retirement life. Again, the current retirement practices of Malaysians which deeply depend on saving, Employees Provident Funds (EPF) and children support are seem to be irrelevant to apply in today scenario.

The study also revealed that, the hypothesis $1\left(\mathrm{H}_{1}\right)$ on age has a significant impact towards retirement planning was accepted. This study was aligned by Richardson and Kilty (1995), where the age has emerged as an important ad consistent factor in human behavior towards retirement planning. Age also help to guide pre-retirees in ground work process of planning (DeVaney, 1995), lead to attitude and perception changes on retirement and also help to raise retirement confidence (Joo \& Pawels, 2002). The hypothesis $2\left(\mathrm{H}_{2}\right)$ on the education level has a significant impact towards retirement planning was also accepted. The results had shown a very strong relationship between education level and retirement planning. The finding supported by Joo \& Pauwels (2002), stated that the education enables individuals to explore more information relating to their retirement planning and that sources of information will influence their decision, attitude and intention to do retirement planning. However, The Hypothesis $3\left(\mathrm{H}_{3}\right)$ is genders has a significant impact towards retirement planning was rejected. Gender difference is also a significant predictor in retirement planning studies. Men is found to be more ready and well prepared for retirement planning compared to women in general (Lusardi \& Mitchell, 2008).Based on the result obtained was contradicted with most of previous researches. It is further supported by Joo and Grable (2001), these researchers highlighted gender difference do not bring any effect to the decision making on retirement and mentioned that the likelihood of both genders' behavior on professional retirement help-seeking are the same. The hypothesis $4\left(\mathrm{H}_{4}\right)$ is income level has a significant impact towards retirement planning was accepted. Income is the most important vehicle to drive people towards a proper retirement planning. The results prove a positive relationship. The data of the study indicated that to begin a retirement planning, sufficient amount or excess of income is needed, otherwise it will be hard to plan. According to Richardson and Kilty (1989), income is important in the sense for retirement preparation. Based on the analysis that had carried out, the results for hypotheses tested were stated in Table 5 as below. 
Table 5. Summary of hypotheses results

\begin{tabular}{lll}
\hline No. of Hypothesis & Statement of Hypothesis & Results \\
\hline $\mathrm{H} 1$ & Age has significant impact towards retirement planning & Accepted \\
$\mathrm{H} 2$ & Education level has significant impact towards retirement planning & Accepted \\
$\mathrm{H} 3$ & Gender has significant impact towards retirement planning & Rejected \\
$\mathrm{H} 4$ & Income level has significant impact towards retirement planning & Accepted \\
\hline
\end{tabular}

\section{Conclusion}

It is concluded that, the retirement planning is very important since the growing life expectancy among Malaysians over the past few decades. The life expectancy has risen drastically of about 2 to 3 years for each decade and expected to further increase in the future. Due to that scenario, financial planning for retirement becomes more important indeed. However, several the problems rise in preparing the retirement plan such as biological aging process, types of worker, retirement age policy, family culture changes, increase medical cost and etc. Again, the existing poor retirement planning practices among Malaysian which relying much on saving, Employees Provident Funds (EPF) and children support, therefore a study on retirement planning particularly among Malaysians are necessarily to be conducted.

Furthermore, the aim of current study is to investigate the factors contribute to the retirement planning among Malaysian specifically in the scope of Health Sectors based employees. Meanwhile, the objectives of the current study are to examine the relationship between demographic factors (i.e. age, education level, gender and household income) towards the retirement planning. The study also revealed that, hypothesis $\mathrm{H}_{3}$ i.e. age was rejected and negatively related however hypothesis $\mathrm{H}_{1}, \mathrm{H}_{2}$, and $\mathrm{H}_{4}$ was accepted and positively related.

Finally, the result of the study profoundly useful in explicating the general practices of pre-retirees towards retirement, as well as contributing much knowledge on the development of new factors related to retirement planning for the future studies. Meanwhile, the findings of this study are sophisticated to benefits the government and policy makers, as well as banking and financial institutions in satisfying the needs and wants from the market.

\section{References}

Bernheim, B. D. (1994). A Theory of Conformity. Journal of Political Economy, 102, 841-877. http://dx.doi.org/ $10.1086 / 261957$

DeVaney, S. A. (1995). Retirement Preparation of Older and Younger Baby Boomer. Financial Counseling and Planning, 6, 25-34.

DeVaney, S. A., Gorham, L., Bechman, J. C., \& Haldeman, V. (1995). Saving and Investing for Retirement: The Effect of a Financial Education Program. Family Economics and Resource Management Biennial, 153-158.

Ekerdt, D. J., \& Clark, E. (2001). Selling retirement in financial planning advertisements. Journal of Aging Studies, 15, 55-68. http://dx.doi.org/10.1016/S0890-4065(00)00016-5

Glass, J. C. Jr., \& Kilpatrick, B. B. (1998). Financial Planning for Retirement: An Imperative for Baby Boomer Women. Educational Gerontology, 24(6), 595-617. http://dx.doi.org/10.1080/0360127980240606

Grable, J. E. (2001). Financial risk tolerance and additional factors that affect risk taking in everyday money matters. Journal of Business and Psychology, 14, 625-630. http://dx.doi.org/10.1023/A:1022994314982

Grace, D., Weaven, S., \& Ross, M. (2010). Consumer retirement planning: An exploratory study of gender differences. Qualitative Market Research: An International Journal, 13(2), 174-188. http://dx.doi.org/10. $1108 / 13522751011032601$

Graham, S., Rogacki, D., Schumann, C., \& Zuberbier, T. (2010). Managing negative attitudes. EMDA.

Greninger, S. A., Hampton, V. L., Kitt, K. A., \& Jacquet, S. (2000). Retirement planning guidelines: A Delphi study of financial planners and educators. Financial Service Review 9, 231-245. http://dx.doi.org/10.1016/ S1057-0810(01)00069-5

Hanisch, K. (1995). Behavioral families and multiple causes. Matching the complexity of responses to the complexity of antecedents. Current directions psychological Science, 4, 156-161. http://dx.doi.org/10.1111/ 1467-8721.ep11512268

Hersey, D. A., Mowen, J. C., \& Jacobs-Lawson, J. M. (2003). An Experimental Comparison of Retirement Intervention Seminars. Educational Gerontology, 29, 339-359. http://dx.doi.org/10.1080/713844333

Hogarth, J. M. (1985). Retirement Planning Education: What Do People Want to Know? When do they want to know it? The Journal of Consumer Education, 3, 21-24. 
HSBC Bank Malaysia Berhad. (2010). Retirement: Have you thought about it lately? Liquid, 5, 1-10. Retrieved from http://biz.thestar.com.my/news/story.asp?file=/2010/3/27/business/5917769\&sec=business

Hunt, L. (2009). Planning for retirement. The Star Online. Retrieved October 25, 2012, from http://biz,thestar.com.my/news/story.asp?file=/2009/8/22/business $/ 4523024 \& s e c=$ business

Jacobs-Lawson, J. M., \& Hershey, D. A. (2005). Influence of future time perspective, financial knowledge, and financial risk tolerance on retirement saving behaviors. Financial Service Review, 14, 331-344.

Joo, S., \& Garman, T. E. (1998). Workers Want More than Retirement Education at Their Workplace: A Report of Research Finding. Personal Finances and Workers Productivity, 2(2), 156-161.

Joo, S., \& Pauwels, V. W. (2002). Factors affecting workers' retirement confidence: A gender perspective: Financial Counseling and Planning, 13(2), 1-10.

Kim, J., Kwon, J., \& Anderson, E. A. (2005). Factors Related to retirement Confidence: Retirement Preparation and Workplace Financial Education. Financial Counseling and Planning Education, 16(2), 77-89.

Kosloski, K., Ekerdt, D., \& Deviney, S. (2001). The Role of Job-Related Rewards in Retirement Planning. The Journal of Gerontology: Psychological Sciences, 56B(3), 160-169. http://dx.doi.org/10.1093/geronb/56. 3.P160

Lim, V. K. G. (2003). An empirical study of older workers' attitudes towards the retirement experience. Employee Relations, 25(4), 330-346. http://dx.doi.org/10.1108/01425450310483361

Lusardi, A., \& Mitchell, O. (2008). Planning and Financial Literacy: How do Women Fare? American Economic Review: Papers \& Proceeding, 98(2), 413-417. http://dx.doi.org/10.1257/aer.98.2.413

Mitchell, O. S., \& Moore, J. F. (2007). Can American afford to retire? New evidence on retirement saving adequacy. The Journal of Risk Insurance, 65, 371-400. http://dx.doi.org/10.2307/253656

Montalto, C. P., Yuh, Y., \& Hanna, S. (2000). Determinants of planned retirement age. Financial Services Review, 9(1), 1-15. http://dx.doi.org/10.1016/S1057-0810(00)00052-4

Muzaffar, C. (2010, August 9). Huge income gap a '1Malaysia' a challenge. Malaysiakini. Retrieved October 25, 2012, from http://www.malaysiakini.com/letters/139586

Parson, T. (1942). Age and sex in the social structure of the United States. American Sociological Review, 7, 604-616. http://dx.doi.org/10.2307/2085686

Richardson, V., \& Kilty, K. M. (1989). Retirement financial planning among black professionals. The Gerontologist, 29, 32-37. http://dx.doi.org/10.1093/geront/29.1.32

Ruhm, C. J. (1989). Why older Americans stop working. The Gerontological Society of America, 29, 294-299. http://dx.doi.org/10.1093/geront/29.3.294

Selene, I. (2005). Maximising the potential for individuals to self-fund their retirement. Paper presented at ASFA NSW Seminar.

Sunden, A. E., \& Surette, B. (1998). Gender Differences in the Allocation of Assets in Retirement Savings Plan. American Economic Review: Papers and Proceedings, 207-211.

Taylor-Carter, M. A., Cook, K., \& Weinberg, C. (1997). Planning and Expectations of the Retirement Experience. Educational Gerontology, 23(3), 273-288. http://dx.doi.org/10.1080/0360127970230306

United Nations Statistics Division. (2010). World Statistics Pocketbook: Malaysia. Retrieved July, 7, 2010, from http://data.un.org/CountryProfile.aspx?crName=Malaysia

Xiao, J. J. (1995). Patterns of household financial asset ownership. Financial Counseling and Planning, 6, 99-106.

Yakoboshi, P., \& Dickemper, J. (1997). Increased Saving but Little Planning: Results of the 1997 Retirement Confidence Survey. Employee Benefit Research Institute (EBRI), 191, 1-21.

Yip, C. (2009, October 31). Redefining Retirement Planning. Retrieved October 25, 2012, from http://biz.thestar.com.my/news/story.asp?file=/2009/10/31/business/4956742\&sec=business

Zappala, S., Depolo, M., Fracaroli, F., Guglielmi, D., \& Sarchielli, G. (2008). Early Retirement as Withdrawal Behaviour: Postponing job retirement? Career Development International, 13(2), 150-167. http://dx.doi.org $/ 10.1108 / 13620430810860558$

\section{Copyrights}

Copyright for this article is retained by the author(s), with first publication rights granted to the journal.

This is an open-access article distributed under the terms and conditions of the Creative Commons Attribution license (http://creativecommons.org/licenses/by/3.0/). 